\title{
OPTIMALISASI PERAN KECAMATAN DALAM PENGELOLAAN KEUANGAN DESA
}

\author{
Zuhrizal Fadhly \\ Fakultas Ilmu Sosial dan Ilmu Politik, Universitas Teuku Umar \\ email: zuhrizalfadhly@gmail.com
}

\begin{abstract}
This research is about Optimalization of District Role in Village Financial Management. The purpose of this study is to optimize the role of sub-districts in village financial management. This study uses normative legal research methods (legal research), ie. studies that refer to the principles, norms contained in laws and regulations, ranging from Laws, Government Regulations, Ministerial Regulations, Regional Regulations/Qanun, Governor Regulations and Regents Regulations relating to the duties of sub-districts in the guidance and supervision village finance. The approach used in this study is the state approach, and the concept approach, by examining the research material consisting of primary, secondary and tertiary legal materials. The research material is analyzed by qualitative approach, with the aim to understand the meaning of the legal material that has been collected, which then interpreted normatively, logically and systematically by using inductive method. The results of this study indicate that the function of guidance and supervision that has been carried by the sub-district does not clearly reveal the intent and how the business process runs. The definition of village financial management is evident in 5 aspects: planning, implementation, administration, reporting, and accountability need to be clarified by stating the extent of the role of the kecamatan in each stage. In the planning aspect, the sub-districts need to be involved intensively when the village government processes the village development planning. This is aimed at ensuring that the development planning prepared by the village government is in line with regional development planning. District / city governments need to facilitate kecamatan to increase their role in supervising village financial management. One thing that can be done is to facilitate kecamatan devices to obtain education, training, in the framework of competence development. Provincial governments can play a role in financing aspects to strengthen the capacity of kecamatan equipment through education and training.
\end{abstract}

Keywords: Optimalization, District, Management of village finances 


\section{PENDAHULUAN}

Kecamatan dalam UU No. 23 Tahun 2014 tentang Pemerintahan Daerah adalah bagian wilayah dari daerah kabupaten/kota. Menurut UU ini, kecamatan merupakan perangkat daerah kabupaten/kota yang melaksanakan urusan pemerintahan yang menjadi kewenangan daerah, dan juga tugas pembantuan. Namun demikian, keberadaan kecamatan selama ini kerap dianggap sebagai unit pemerintahan yang membingungkan. Keberadaannya yang berada di antara kabupaten dengan desa/kelurahan hanya memperpanjang rantai birokrasi. Sementara tugas dan fungsinya hanya sebatas koordinasi, pembinaan, dan pengawasan. Terbitnya undang-undang No. 6 tahun 2014 tentang Desa membuat pemerintah harus mereposisi peran kecamatan, terutama mengenai bagaimana mendorong peningkatan kapasitas pemerintahan desa. Sejak masa Orde Baru, relasi antara kecamatan dan desa digambarkan hierarkis. Baru ketika undangundang No. 22 tahun 1999 dan undang-undang No. 32 tahun 2004 tentang Pemerintahan Daerah, hubungan ini diatur ulang. Pada undang-undang No. 32 tahun 2004, relasinya masih terlihat semi-hirarkis karena keberadaan Sekretaris Daerah yang berstatus sebagai perangkat kecamatan. Baru setelah undang-undang Desa terbit, hubungan hirarkis ini dihapuskan.

Tujuan diundangkannya undang-undang Desa sendiri adalah (a) mendorong prakarsa, gerakan, dan partisipasi masyarakat desa untuk pengembangan potensi dan aset desa guna kesejahteraan bersama; (b) membentuk pemerintahan desa yang profesional, efisien, dan efektif, terbuka, serta bertanggung jawab; (c) meningkatkan pelayanan publik bagi warga masyarakat desa guna mempercepat perwujudan kesejahteraan umum; (d) memajukan perekonomian desa serta mengatasi kesenjangan pembangunan nasional; dan (e) memperkuat masyarakat desa sebagai subjek pembangunan. Artinya, undang-undang Desa menghendaki adanya suatu transformasi pemerintahan dalam penyelenggaraan masyarakat desa, dari pemerintahan yang cenderung tradisional selama ini menjadi suatu pemerintahan yang modern dengan penguatan pada prakarsa dan kemandirian lokal.

Meski demikian, undang-undang Desa tidak sepenuhnya membebaskan desa untuk menjalankan roda pemerintahan tanpa supervisi pemerintahan diatasnya. Undang-undang ini mengamanatkan bahwa dalam rangka penguatan kapasitas pemerintah desa, pemerintah pusat dan daerah, kabupaten/kota, ditugaskan untuk melakukan pembinaan dan pengawasan (Pasal 112-115). Limpahan kewenangan yang luas jelas berimplikasi pada bagaimana kesiapan pemerintah desa mengelola kewenangan-kewenangan itu. Salah satunya yang paling penting terkait kewenangan pengelolaan keuangan desa. Karena undang-undang Desa mengamanatkan adanya dana desa dan alokasi dana desa yang harus dimanfaatkan oleh desa sebaik mungkin untuk pembangunan desa maka, pembinaan dan pengawasan dari pemerintah daerah dalam hal ini sangatlah penting. Disinilah pemerintah dapat memanfaatkan keberadaan kecamatan untuk memaksimalkan fungsi pembinaan dan pengawasan tersebut. Menurut undang-undang Desa dan undang-undang Pemerintah Daerah, kecamatan disamping mengelola potensi internalnya, juga wajib memberikan pembinaan kepada pemerintahan desa dan pemberdayaan masyarakat desa, sehingga tujuan pengaturan desa yang berdaya dan mandiri dapat tercapai.

\section{Tantangan Kecamatan Dalam Pengelolaan Keuangan Desa}

Seperti telah disebutkan di atas bahwa selama ini, posisi kecamatan dalam struktur hierarki sistem pemerintahan di Indonesia memang tergolong menimbulkan pertanyaan. Keberadaannya yang berada dalam wilayah kabupaten/kota dipandang sebagai hal yang membingungkan. Satu sisi ia merupakan bagian dari organisasi perangkat daerah, tidak memiliki urusan pemerintahan yang spesifik, tetapi memiliki wilayah kerja administratif. Tugas dan fungsinya terbatas hanya dalam hal pelaksanaan fungsi-fungsi pemerintahan umum yaitu melakukan pembinaan dan pengawasan masyarakat. Dalam hubungannya dengan desa, sejak diterbitkan undang-undang No. 5 tahun 1974 tentang Pokok-Pokok Pemerintahan di Daerah, relasi kecamatan dengan desa diletakkan pada hubungan hierarkis. Pemerintah ingin meletakkan posisi negara di atas desa 
melalui kecamatan yang dilimpahkan kuasa menjadi kepala wilayah, dimana desa menjadi subordinasinya. Namun, pasca Orde Baru, beberapa undang-undang Pemerintah Daerah, begitu juga undang-undang Desa, ingin mengatur kembali relasi negara dengan desa. Definisi desa dikembalikan sesuai dengan amanat konstitusi bahwa negara mengakui dan menghormati keberadaan kesatuan masyarakat hukum yang memiliki kewenangan mengatur dan mengurus rumah tangganya sesuai dengan prakarsa lokal dan hak asal usul. Keberadaannya yang dianggap otonom ini menjadikan relasi antar kewenangan antara kecamatan dan desa menjadi berubah.

Pemerintah pun kemudian mengeluarkan beberapa peraturan yang mengatur peran kecamatan dalam tata kelola pemerintahan desa. PP No. 19 tahun 2008 secara khusus menjabarkan fungsi dan wewenang kecamatan, namun sayangnya, ketika undang-undang No. 32 tahun 2004 diganti dengan undang-undang No. 23 tahun 2014, belum dilengkapi dengan regulasi terkait peran kecamatan secara terperinci. Di undang-undang Desa peran camat hanya disebutkan secara eksplisit yaitu mengangkat perangkat desa, koordinasi, sementara peran dalam pembinaan dan pengawasan hanya ketika dimandatkan. Pada PP No. 43 tahun 2014 tentang Peraturan Pelaksanaan undang-undang Desa, terdapat penjelasan tentang tugas pembinaan dan pengawasan desa, namun, penjelasan itu masih kurang spesifik karena hanya disebutkan tugas pemfasilitasan dan pengkoordinasian berbagai tugas dan tanggung jawab pemerintah desa.

Pada undang-undang No. 6 tahun 2014, peran kecamatan dalam fungsi pembinaan dan pengawasan desa memang tidak disebut secara komprehensif. Kewenangannya disesuaikan dengan tugas yang diemban oleh kabupaten/kota. Sesuai Pasal 115, pemerintah kabupaten/kota melakukan pembinaan dan pengawasan penyelenggaraan pemerintahan desa. Pada PP No. 43 tahun 2014 disebutkan pada Bab XI Pasal 154 bahwa Camat (setelah menerima limpahan delegatif dari bupati/walikota) mengemban tugas pembinaan dan pengawasan desa. Terdapat 18 tugas utama yang diberikan kepada Camat dalam melakukan fungsi binwas tersebut. Dalam penelitian yang dilakukan oleh Pusat Kajian Desentralisasi dan Otonomi Daerah, Lembaga Administrasi Negara mengenai hubungan kewenangan pemerintah pusat dan daerah dengan pemerintah desa terkait mengelola keuangan desa, ditemukan bahwa selama ini masih banyak pemerintah desa belum sepenuhnya mandiri dalam mengelola keuangan desanya sendiri (PKDOD, 2016). Peran kecamatan dan pendamping desa sangat diperlukan dalam melakukan supervisi kepada pemerintah desa. Mengingat kewenangannya yang sebatas pembinaan dan pengawasan, maka besar kewenangan kecamatan sangat bergantung pada besar kecilnya pelimpahan kewenangan yang diberikan Bupati/Walikota kepada Camat. Pada aspek pengelolaan keuangan desa, Pasal 154 ayat 2 PP No. 43 tahun 2014 menyebutkan tugas kecamatan yang berkaitan dengan pengelolaan keuangan desa, yaitu:

1. Pada huruf a pasal 154 ayat 2 disebutkan Camat memiliki tugas "melakukan fasilitasi penyusunan peraturan desa dan peraturan kepala desa." Pada tataran implementasi, melalui Permendagri No. 113 tahun 2014 tentang Pengelolaan Keuangan Desa, pada pasal 21 ayat 1 menyebutkan bahwa "Rancangan Peraturan Desa tentang APBDes yang telah disepakati bersama sebagaimana dimaksud dalam Pasal 20 ayat (3) disampaikan oleh Kepala Desa kepada Bupati/Walikota melalui camat atau sebutan lain paling lambat 3 (tiga) hari sejak disepakati untuk dievaluasi." Artinya dalam aspek perencanaan, Camat diberikan tugas untuk mengevaluasi rancangan Perdes mengenai APBDes sebelum disampaikan kepada bupati/walikota. Disini, tugas Camat sangat besar untuk memastikan bahwa rencana pembangunan yang disusun oleh Pemerintah Desa telah sesuai dengan perencanaan pembangunan kabupaten/kota.

2. Pada huruf $\mathrm{c}$, Camat melakukan pembinaan dan pengawasan dengan cara memfasilitasi pengelolaan keuangan desa dan pendayagunaan aset desa. Dalam aturan ini kurang jelas dengan apa yang dimaksud dengan pengelolaan keuangan desa. Dalam PP No. 43 tahun 2014 disebutkan pada pasal 93 yang dimaksud dengan pengelolaan keuangan daerah 
meliputi perencanaan, pelaksanaan, penatausahaan, pelaporan, dan pertanggungjawaban. Pertanyaannya apakah dalam memfasilitasi pengelolaan keuangan desa, posisi camat terlibat dalam kelima aspek tersebut.

Meski demikian, aturan-aturan tersebut belum secara jelas menjabarkan peran kecamatan dalam pengelolaan keuangan desa. Setidaknya pemerintah perlu memperjelas definisi pengelolaan keuangan desa yang dijabarkan dalam 5 aspek tadi, perencanaan, pelaksanaan, penatausahaan, pelaporan, dan pertanggungjawaban. Ditambah, jumlah desa di seluruh Indonesia yang mencapai 74.754 , karakteristik dan tipologinya beragam. Kementerian Desa misalnya membagi tipologi desa di Indonesia menjadi desa tertinggal, desa berkembang, dan desa mandiri yang didasarkan pada 5 karakteristik yaitu, kekerabatan desa, hamparan, pola pemukiman, mata pencaharian (masyarakatnya); dan/atau tingkat perkembangan kemajuan desa. Sementara Bappenas membagi desa-desa di Indonesia ke dalam lima tipologi yaitu, desa tertinggal, desa berkembang, desa mandiri, desa maju, dan desa sejahtera. Dari beragam tipologi tersebut menunjukkan bahwa desa-desa di Indonesia tidaklah sama jika dilihat dari dua aspek utama seperti sumber daya manusia dan sumber daya alamnya. Oleh karena itu, penanganan atau supervisi yang dilakukan oleh pemerintah daerah pun tidak bisa sama. Disamping aspek regulasi serta karakter desa, aspek sumber daya manusia di kecamatan pun menjadi concern penting dalam penguatan perannya di dalam pengelolaan keuangan desa. Selama ini kecamatan kerap dijadikan sebagai tempat berkumpulnya para pegawai negeri kelas II yang secara kompetensi dan pendidikan tergolong rendah dibandingkan SKPD seperti dinas. Maka dari itu, mengingat begitu pentingnya peran dalam pengelolaan keuangan desa ini, diperlukan sebuah tindak lanjut yang komprehensif untuk mengatasi persoalan ini.

\section{METODE PENELITIAN}

Kajian ini menggunakan metode penelitian hukum normatif (legal research), yaitu. kajian yang mengacu kepada asas-asas, norma-norma yang terdapat dalam peraturan perundangundangan, mulai dari Undang-Undang, Peraturan Pemerintah, Peraturan Menteri, Perda/Qanun, Peraturan Gubernur dan Peraturan Bupati yang berkaitan dengan tugas kecamatan dalam pembinaan dan pengawasan keuangan desa. Pendekatan yang digunakan dalam kajian ini, yakni pendekatan perundangan-undangan (state approach), dan pendekatan konseptual (concept approach), dengan mengkaji bahan penelitian yang terdiri dari bahan hukum primer, sekunder dan tersier. Bahan penelitian dianalisis dengan pendekatan kualitatif, dengan tujuan untuk memahami makna dari bahan hukum yang telah dikumpulkan, yang kemudian ditafsirkan secara normatif, logis dan sistematis dengan menggunakan metode induktif.

\section{HASIL DAN PEMBAHASAN}

\section{Pengelolaan Alokasi Dana Desa (ADD)}

a. Perencanaan ADD

Perencanaan ADD dilakukan dengan menjaring aspirasi dan kebutuhan masyarakat melalui musyawarah desa atau rembug desa. Musyawarah desa dilakukan pembahasan mengenai perencanaan Anggaran Pendapatan dan Belanja Desa (APBDes), serta Musyawarah Rencana Pembangunan Desa (Musrembangdes) sehingga dihasilkan Rencana Penggunaan Dana (RPD). Perencanaan ADD dilakukan dengan perencanaan partisipatif melalui musyawarah desa. Tingginya tingkat partisipasi masyarakat dalam pelaksanakan musyawarah desa dapat dilihat dari tingkat kehadiran dan jumlah usulan oleh masyarakat. Fenomena dilapangan tersebut sesuai dengan teori pemberdayaan oleh Ife dalam Suharto (2005, h.59) yang menjelaskan bahwa pemberdayaan masyarakat dapat dilihat dari pendefinisian kebutuhan yakni kemampuan menentukan kebutuhan selaras dengan aspirasi dan keinginannya. Pemberdayaan masyarakat juga dapat dilihat dari pendefinisian ide dan gagasan yakni kemampuan mengekspresikan dan menyumbangkan gagasan dalam suatu forum atau diskusi secara bebas dan tanpa tekanan. 


\section{b. Penganggaran ADD}

Penganggaran ADD dilakukan setelah hasil dari musyawarah desa disetujui oleh seluruh pihak yang terkait di desa, sehingga dapat disusun Rencana Penggunaan Dana (RPD) selama satu tahun berjalan. RPD tersebut memuat penggunaan dana ADD untuk pemberdayaan masyarakat dan operasional pemerintah desa. RPD desa dalam pelaksanaannya sebenarnya tidak sesuai dengan ketentuan, dimana dana untuk operasional Badan Permusyawaratan Desa (BPD) tidak dimasukkan dalam RPD Operasional Pemerintah desa. Namun dana operasional BPD tersebut justru dimasukkan dalam RPD pemberdayaan masyarakat. Kejadian tersebut sebenarnya bertentangan Peraturan Menteri Dalam Negeri Nomor 13 tahun 2014 tentang Pedoman Pengelolaan Keuangan Desa. Dalam peraturan tersebut, ditetapkan bahwa penggunaan anggaran ADD adalah sebesar 70\% untuk Pemberdayaan Masyarakat dan sebesar 30\% untuk biaya Operasional Pemerintah Desa dan BPD.

c. Mekanisme pencairan dan penyaluran ADD

Mekanisme pencairan dan penyaluran ADD, secara teknis ada beberapa tahap yang harus di lalui, yaitu sebagai berikut : setelah semua berkas pengajuan ADD lengkap dan dalam berkas pengajuan mengetahui camat, kemudian bersama-sama desa se kecamatan diajukan ke Bagian Tata Pemerintahan Desa Sekretariat Daerah Kabupaten/Kota. Kemudian Bagian Pemerintahan Desa pada Sekretariat Daerah Kabupaten/Kota akan meneruskan berkas permohonan berikut lampirannya kepada Kepala Dinas Pendapatan, Pengelolaan Keuangan dan Asset Daerah (DPPKAD). Apabila semua persyaratan sudah dipenuhi maka DPPKAD segera mentransfer dana ADD ke rekening Pelaksana Teknis Pengelolaan Keuangan Desa (PTPKD). Mekanisme penyaluran dan pencairan ADD sudah sesuai dengan peraturan yang mengatur pengelolaan keuangan desa yaitu Peraturan Menteri Dalam Negeri Nomor 113 Tahun 2014 tentang Pedoman Pengelolaan Keuangan Desa.

d. Penggunaan ADD

Penggunaan ADD untuk pemberdayaan masyarakat dalam bidang penanggulangan kemiskinan, penggunaan dana di gunakan untuk biaya operasional pendistribusian raskin, program bedah rumah dan program plesterisasi. Hal tersebut merupakan pencapaian pemberdayaan masyarakat dengan kecenderungan primer. Berdasarkan teori pemberdayaan oleh Pranaka dan Vindhayanika dalam Prasojo (2003, h.12) kecenderungan primer merupakan proses pemberdayaan ditekankan pada proses pemberian atau pengalihan sebagian kekuasaan, kekuatan dan kemampuan kepada masyarakat atau individu agar menjadi lebih berdaya. Dalam hal peningkatan pendapatan desa, banyak desa belum memiliki Badan Usaha Milik Desa (BUMDes) dalam pengalokasian ADD juga belum ada anggaran untuk pembentukan BUMDes. Dalam penggunaan dana untuk pening-katan derajat kesehatan yaitu dengan memberikan bantuan kepada Pos Pelayanan Terpadu (Posyandu). Dimana biaya tersebut diperuntukan untuk membiayai kegiatan-kegiatan posyandu balita maupun posyandu lansia. Hal tersebut sesuai dengan teori pemberdayaan oleh Ife dalam Suharto (2005, h.59) yang menjelaskan bahwa pemberdayaan dapat dilihat dari kemampuan dalam kaitannya dengan proses kelahiran dan perawatan anak.

Berdasarkan teori pemberdayaan masyarakat oleh Ife dalam Suharto (2005, h.55) yang menjelaskan bahwa pemberdayaan masyarakat dapat dilakukan dengan meningkatkan kemampuan menjangkau, mengunakan dan mempenggaruhi pranata-pranata masyarakat, seperti lembaga kese-jahteraan sosial, pendidikan, kesehatan. Pada bidang pendidikan, penggunaan dana ADD untuk peningkatan pendidikan luar sekolah yaitu dengan memberikan bantuan untuk operasional kegiatan belajar mengajar pada TK dan Paud. Dalam pemanfaatannya sebenarnya sudah sesuai, namun terlalu kecilnya dialokasikan merupakan kelemahan dalam peningkatan kualitas pendidikan. Hal tersebut sesuai dengan tingkat pendidikan terakhir penduduk desa yang mayoritas lulusan SD dan SMP. Alangkah baiknya apabila pemerintah desa meningkatkan anggaran untuk bidang pendidikan dan menggunakan dana tersebut untuk menunjang kegiatan- 
kegiatan pendidikan selain sekolah seperti Taman Pendidikan Qur'an (TPQ) maupun pendidikan dan pelatihan kelompok-kelompok tani.

e. Pengawasan ADD

Pengawasan dilakukan terhadap jalannya pemerintahan dan pembangunan agar dalam pelaksanaannya tidak menyimpang dari rencana yang telah ditetapkan dan aturan yang berlaku berdasarkan terdahap pelaksanaan fisik maupun pengelolaan keuangan. Pengawasan pengelolaan ADD secara fungsional yakni pengawasan oleh aparat pengawas atau satuan organisasi pemerintah Kabupaten/Kota maupun Kecamatan yang menyelenggarakan pengawasan. Berdasarkan pengamatan peneliti, pengawasan secara fungsional pada desa yang berupa pelaporan yang seharusnya dilakukan setiap bulan (Laporan Berkala) dan setiap akhir tahun (SPJ), namun pada pelaksanaannya hanya dilakukan 3 kali dalam satu tahun. Apabila dikaitkan dengan peraturan yang mengatur mengenai pengawasan pengelolaan ADD yakni Peraturan Menteri Dalam Negeri Nomor 13 Tahun 2014 tentang Pedoman Pengelolaan Keuangan Desa, menjelaskan bahwa pemerintah pemerintah Provinsi wajib mengkoordinir pemberian dan penyaluran ADD dari Pemerintah Kabupaten. Sedangkan Pemerintah Kabupaten dan Camat wajib membina dan mengawasi pelaksanaan pengelolaan keuangan desa. Berdasarkan fenomena di lapangan, pengawasan oleh Pemerintah Provinsi, Kabupaten, maupun Camat yang terjadi dalam pengelolaan ADD pada desa belum sesuai dengan aturan yang berlaku, masih perlu ditingkatkan dalam kuantitasnya dan kualitas pengawasan.

Pengawasan secara melekat yaitu pengawasan yang dilakukan oleh atasan langsung melalui struktur organisasi, bagan organisasi dengan rentang kendali yang tegas dengan pembagian tugas dan fungsi beserta uraian tugas pekerjaan yang jelas. Peneliti melihat bahwa pengawasan melekat pada desa telah dilaksanakan oleh Kepala Desa, perangkat desa dan masing-masing ketua pelaksana kegiatan. Berdasarkan hasil penelitian, belum terjadi pengawasan secara langsung oleh masyarakat dalam pengelolaan ADD. Hal tersebut terjadi dikarenakan kurang pahamnya masyarakat akan adanya program ADD sehingga perlu adanya sosialisasi dan transparansi penggunaan dana ADD dari pemerintah desa.

f. Pertanggungjawaban ADD

Pertanggungjawaban merupakan bentuk konsekuensi atas penggunaan dana publik yang dipercayakan kepada pemerintah desa. Dilihat dari bentuk pertanggungjawaban, desa cenderung bersifat administratif. Pertanggungjawaban administratif merupakan pertanggungjawaban pemerintah desa atas kegiatan pelaksanaan ADD secara administratif berupa Surat Pertanggung Jawaban (SPJ) ADD atas pengawasan Camat kepada Bupati melalui Bagian Tata Pemerintahan Desa Sekretariat Daerah Kabupaten/Kota. Menurut Peraturan Menteri Dalam Negeri Nomor 113 tahun 2014 tentang Pedoman Pengelolaan Keuangan Desa, bahwa pertanggungjawaban disampaikan dalam bentuk pelaporan hasil pelaksanaan pengelolaan ADD.

Pelaporan dilakukan setiap bulan (Laporan Berkala) dan setiap akhir tahun (SPJ) dan dilaksanakan secara struktural dari Kepala Desa kepada Camat, kemudian oleh Camat diteruskan Kepada Bupati/Walikota. Namun dalam pelaksanaannya, pertanggungjawaban ADD hanya dilakukan hanya 3 kali dalam setahun yakni pada saat untuk pencairan ADD tahap selanjutnya dan tahun selanjutnya bahkan pada awal di implementasikan program ADD pertanggungjawaban hanya dilakukan pada akhir tahun.

Berdasarkan pengamatan peneliti bahwa belum terjadi pertanggungjawaban secara langsung kepada masyarakat. Hal tersebut terjadi karena belum ada transparansi atau keterbukaan oleh pemerintah desa sebagai pengelola ADD kepada masyarakat dalam bentuk informasi penggunaan dana ADD. Analisis tersebut juga didukung oleh kenyataan bahwa pelaksanaan kegiatan fisik yang didanai ADD diserahkan kepada kepala dusun atau perangkat desa, sedangkan sebagian besar tidak pernah menginformasikan kepada masyarakat tentang dana yang diterimanya. Hal tersebut bertentangan dengan ketentuan yang ada, bahwa kegiatan yang 
bersumber dari ADD harus dipertanggungjawabkan secara langsung kepada masyarakat dan BPD serta pelaksanaan ADD harus dilakukan secara Partisipatif, Transparan, dan Akuntabel.

\section{Peran Pemerintah Kecamatan Dalam Pelaksanaan Pembinaan Dan Pengawasan Penyelenggaraan Administrasi Desa}

a. Pembinaan

Kegiatan yang dilakukan oleh pemerintah kecamatan yaitu dengan mengadakan pembinaan kepada perangkat desa tentang penyelenggaraan administrasi desa. Pembinaan untuk desa ini dilaksanakan untuk membantu dan memberikan pengarahan mengenai administrasi desa dan laporan pertanggung jawaban penyelenggaraan pemerintahan desa, sehingga desa tidak kesulitan dalam pelengkapan mengenai administrasi desa. Kegiatan pembinaan tersebut untuk meningkatkan sumber daya manusia perangkat desa yang meliputi bimbingan dan pelatihan kepada desa. Pembinaan yang dilakukan pemerintah kecamatan yaitu :

1) Tata cara penyusunan administrasi desa

2) Proses pengelolaan keuangan

3) Petunjuk teknis yang dilaksanakan di desa

4) Pembinaan penyelenggaraan pemerintah desa

5) Memfasilitasi penyusunan administrasi desa

Meskipun telah dilakukan pembinaan namun karena minimnya sumber daya manusia, perkembangan ilmu administrasi aparat desa serta dukungan peralatan yang belum memadai sehingga sedikit menghambat untuk pelengkapan data administrasi desa.

b. Bimbingan

Bimbingan yang dilakukan adalah bimbingan untuk proses pembuatan peraturan desa, peraturan kepala desa, maupun keputusan kepala desa, sehingga produk hukum yang dimaksud tidak bertentangan dengan peraturan perundang-undangan yang berlaku. Pemerintah Kecamatan memberikan penjelasan kepada perangkat desa tentang pentingnya tujuan administrasi. Bimbingan pemberian materi-materi dan pengarahan yang berkaitan dengan pelaksanaan pembukuan seperti administrasi desa, pembuatan laporan pertanggungjawaban (LPJ), anggaran pendapatan belanja desa (APBDes), perubahan anggaran pendapatan belanja desa, rancangan pembangunan jangka menengah desa (RPJMDes), dan surat menyurat yang dilakukan oleh Sekretaris Kecamatan. Kecamatan juga melakukan kegiatan pengarahan tentang teknis operasional administrasi dalam bentuk kegiatan sosisalisasi dan training melalui kepala seksi.

c. Pelatihan

Pelatihan diberikan kepada perangkat desa, guna meningkatkan standar operasional administrasi desa sesuai standar prosedur yang ada. Karena administrasi yang sesuai akan bermanfaat bagi perkembangan dan kemajuan suatu desa, sehingga masyarakat merasa puas dengan kinerja kepala desa dan perangkatnya. Pelatihan dilaksanakan oleh pemerintah kecamatan baik camat, sekretaris kecamatan atau kepala seksi pemerintahan. Dalam pelatihan tersebut pemerintah kecamatan memberikan pelatihan tata cara penyusunan baik administrasi umum, keuangan, kependudukan, dan pembangunan. Pelatihan yang diikuti oleh perangkat desa diharapkan nantinya perangkat desa mampu mrengerjakan tugas-tugasnya dengan baik yang dibebankan kepadanya tanpa arahan langsung dari atasannya. Pelatihan ini dilaksanakan bertujuan untuk meningkatkan kemampuan perangkat desa dalam mengolah kegiatan sesuai dengan profesi dalam melayani kepentingan masyarakat. Selain melakukan kegiatan bimbingan dan pelatihan di desa, kecamatan juga memberikan bimbingan dan pelatihan secara menyeluruh terhadap seluruh aparat desa yang dilaksanakan di kantor kecamatan. Hal yang dilakukan oleh pemerintah kecamatan adalah berupa penjelasan kembali tentang cara mengisi pembukuan sesuai dengan standarisasi jenis dan bentuk administrasi untuk perangkat desa yang belum sepenuhnya paham. 


\section{d. Pengawasan}

Pemerintah Kecamatan selain melakukan pembinaan juga melakukan pengawasan terhadap perangkat desa dalam melaksanakan kegiatan pemerintahan desa. Pengawasan dilakukan dengan memantau kegiatan aparat desa dan memeriksa kelengkapan administrasi desa yang menjadi bagian dari wilayah kerjanya. Tujuan pelaksanaan pengawasan yaitu untuk mengetahui hasil kerja yang dijalankan oleh pemerintah desa, apakah sudah sesuai atau masih ada kekurangan dalam menjalankan kegiatan administrasi. Pemerintah kecamatan dalam melakukan pengawasan terbagi atas pengawasan langsung dan pengawasan tidak langsung yang dilakukan oleh perangkat kecamatan yaitu camat, sekretaris kecamatan dan seksi tata pemerintahan. Pengawasan langsung dilakukan dengan datang ke desa untuk memantau sekaligus pengecekan kegitan yang dilaksanakan oleh aparat desa dalam menjalakan pemerintahan, melayani dan mengurus kebutuhan warganya. Pengawasan tidak langsung dilakukan oleh perangkat kecamatan melalui laporan administrasi desa yang dikumpulkan ke kecamatan setiap tahun. Hal ini juga dapat meningkatkan efektifitas kerja aparat desa dan lebih disiplin dalam melaksanakan pekerjaanya. Kecamatan mengawasi kegiatan yang dilakukan oleh perangkat desa dalam tugas dibidang pemerintahan dan juga pelayanan kepada masyarakat yang berkaitan dengan administrasi. Selain melaksanakan pembinaan dan pengawasan terhadap kepala desa, pemerintah kecamatan juga mempunyai tugas pembinaan dan pengawasan terhadap perangkat desa, dan melakukan evaluasi penyelenggaraan pemerintahan desa. evaluasi yang dilakukan dengan melihat hasil pengawasan langsung dan laporan pelaksanaan administrasi desa yang dilaporkan ke kecamatan. Pengawasan yang dilakukan terhadap desa meliputi :

2) Hone visit (turun langsung ke desa)

3) Sistem kerja tunggu di tempat

4) Sidak (kegiatan evaluasi)

5) Teguran langsung dan teguran tertulis terhadap aparat

\section{Hambatan Yang Dihadapi Pemerintah Kecamatan Dalam Pelaksanaan Pembinaan Dan Pengawasan Penyelenggaraan Administrasi Desa}

Pemerintah kecamatan dalam melaksanakan pembinaan dan pengawasan administrasi desa mengalami beberapa hambatan yaitu sumber daya manusia dan ketepatan waktu dalam penyerahan laporan kegiatan pemerintahan desa. Walaupun pemerintah kecamatan telah melakukan pembinaan dan pengawasan di desa namun masih terdapat beberapa faktor yang menghambat dalam pelengkapan administrasi desa yaitu ada beberapa perangkat desa yang latar belakang pendidikan yang hanya lulus SMP sehingga dalam melaksanakan pekerjaan belum maksimal, data yang diberikan oleh masyarakat berupa luas lahan/tanah tidak sesuai dengan data yang ada dilapangan karena menghindari pembengkakan biaya pajak, serta kelalaian aparat desa dalam pendataan. Salah satu faktor penghambat dalam pelekengkapan administrasi desa yaitu kemampuan serta sumber daya manusia yang belum memadai dan merupakan desa pemekaran yang baru sehingga masih membutuhkan penyesuaian pekerjaan aparat desa sesuai bidangnya masing-masing.

Hambatan sumber daya manusia yang dimaksud berupa kurangnya staf yang mempunyai keahlian dan kemampuan di desa dan jumlah yang belum memadai yang ada dalam susunan organisasi desa, serta kemampuan yang belum sesuai dengan bidang yang diampu menjadi kendala dalam pelaksanaan pemerintahan di desa sehingga menyebabkan kesulitan dalam proses pelengkapan administrasi desa. hal ini berdampak pada keterlambatan penyerahan laporan ke kecamatan baik laporan keuangan atau laporan yang berkaitan dengan kegiatan administrasi di desa. Keterlambatan dalam penyerahan laporan menyebabkan kegiatan evaluasi pemerintahan kecamatan juga menjadi terhambat. Untuk mengatasi hal tersebut, pihak pemerintah kecamatan selalu memberikan peringatan dan pengarahan serta teguran baik secara lisan ataupun tertulis kepada pemerintah desa yang selalu terlambat dalam menyerahkan laporan kegiatan untuk 
segera melengkapi dan mengumpulkan laporan kegiatan secepatnya sesuai dengan waktu yang telah ditentukan.

Dalam meningkatkan manajemen Pemerintahan Desa perlu dilakukan penataan baik aparat maupun administrasi yang ada di desa agar lebih efektif dan efisien, penataan administrasi merupakan pencatatan data dan informasi dalam mendukung penyelenggaraan Pemerintahan Desa, maka perlu dilakukan langkah penyempurnaan terhadap pelaksanaan administrasi desa. Penataan aparat desa dilakukan untuk lebih disiplin waktu, lebih giat bekerja serta diharapkan dapat memahami apa yang dijelaskan pada waktu pemberian bimbingan dan pelatihan oleh pemerintah kecamatan sehingga aparat desa dapat melaksanakan tugas sesuai dengan bidang pekerjaannya. Jika dilihat dari secara keseluruhan gambaran umum pelaksanaan pembinaan dan pengawasan yang dilakukan oleh pemerintah kecamatan sudah sesuai dengan ketentuan yang telah ditetapkan walaupun masih ada sedikit hambatan yang dihadapi.

\section{SIMPULAN}

Dimensi pengelolaan keuangan menjadi salah satu poin penting dari perubahan tata kelola pemerintahan desa berdasarkan undang-undang Desa. Perubahan ini tidak hanya menyangkut tentang pemerintah desa itu sendiri yang akan menjalankan fungsi otonomnya tersebut, namun juga pada bagaimana peran unit pemerintah diatasnya (supradesa) dalam melakukan supervisi terhadap pemerintah desa. Dalam hal ini, peran kecamatan sangat penting sebagai penengah antara pemerintah daerah dengan desa.

Berdasarkan permasalahan dan tantangan yang disebutkan di atas, maka penulis dapat menarik simpulan beberapa poin penting yang dapat dijadikan sebagai alternatif kebijakan pemerintah atau dimuat dalam regulasi terkait peran kecamatan, khususnya dalam pengelolaan keuangan desa, sebagai berikut : Pertama, Pemerintah melalui Kementerian Dalam Negeri perlu memperjelas fungsi dan kewenangan kecamatan dalam fungsi pengelolaan keuangan desa. Fungsi pembinaan dan pengawasan yang selama ini diemban oleh kecamatan tidak secara jelas menampakkan maksud dan bagaimana proses bisnisnya berjalan. Definisi mengenai pengelolaan keuangan desa yang terjabar dalam 5 aspek yaitu perencanaan, pelaksanaan, penatausahaan, pelaporan, dan pertanggungjawaban perlu diperjelas dengan menyebutkan seberapa jauhkah peran kecamatan dalam setiap tahapan tersebut. Kedua, Pada aspek perencanaan, kecamatan perlu dilibatkan secara intensif ketika pemerintah desa melakukan proses penyusunan perencanaan pembangunan desa. Hal ini ditujukan untuk memastikan bahwa perencanaan pembangunan yang disusun oleh pemerintah desa telah sesuai dengan perencanaan pembangunan daerah. Jadi, dalam hal ini peran Camat tidak hanya sebatas melakukan evaluasi, tetapi juga mengarahkan selama perencanaan yang disusun tersebut benar-benar memperhatikan aspirasi dan partisipasi masyarakat. Ketiga, Terkait dengan tipologi desa, desa-desa yang selama ini diklasifikasikan masuk ke dalam kategori desa yang belum mandiri atau prasejahtera, maka peran kecamatan dapat dioptimalkan dengan keterlibatan mereka dalam seluruh aspek pengelolaan desa. Hal ini bukan bermaksud untuk meminggirkan aspek kemandirian desa, namun hal ini dilakukan dalam rangka meningkatkan kapasitas perangkat desa terlebih dahulu sampai mereka dapat secara mandiri menyusun program pembangunannya sendiri. Keempat, Pemerintah kabupaten/kota perlu memfasilitasi kecamatan untuk meningkatkan perannya dalam supervisi pengelolaan keuangan desa. Satu hal yang dapat dilakukan adalah dengan memfasilitasi perangkat kecamatan untuk memperoleh pendidikan, pelatihan, dalam rangka pengembangan kompetensi. Kelima, Sama halnya dengan pemerintah kabupaten/kota, pemerintah provinsi dapat berperan dalam aspek pembiayaan untuk penguatan kapasitas perangkat kecamatan melalui pendidikan dan pelatihan.

\section{REFERENSI}

Bappenas dan BPS, 2014. Indeks Pembangunan Desa. Jakarta: Bappenas dan BPS. 
Kementerian Desa, Pembangunan Daerah Tertinggal, dan Transmigrasi, 2015. Indeks Desa Membangun, Jakarta: KDPDTT.

Prasojo, Eko. 2003. People And Society Empowerment: Perspektif Membangun Partisipasi Publik.

Jurnal Ilmiah Publik, vol IV, No. 2, Maret-Agustus: 10-24.

Permendagri Nomor 113 Tahun 2014 tentang Pengelolaan Keuangan Desa.

Permendes Nomor 21 Tahun 2015 tentang Prioritas Penggunaan Dana Desa Tahun 2016.

PP Nomor 43 Tahun 2014 tentang Peraturan Pelaksanaan UU Nomor 6 Tahun 2014 tentang Desa.

Sugiono, 2009. Metode Penelitian Kuantitatif \& Kualitatif. Bandung: Alfabet.

Suharto, Edi. 2005. Membangun Masyarakat Memberdayakan Rakyat. Bandung: Refika Aditama.

Sumaryadi, I Nyoman. 2005. Perencanaan Pembangunan Daerah Otonom dan Pemberdayaan

Masyarakat. Jakarta: Citra Utama.

Tjokroamidjojo, Bintoro. 1995. Pengantar Administrasi Pembangunan.

Jakarta: PT. Gunung Agung.

Tim Peneliti Pusat Kajian Desentralisasi dan Otonomi Daerah (PKDOD) LAN. 2016. Model danInstrumentasi Kebijakan Hubungan Kewenangan Pemerintah, Pemerintah Provinsi, Pemerintah Kabupaten/Kota dan Pemerintah Desa dalam Penyelenggaraan Pemerintahan

Desa. Jakarta: PKDOD LAN.

UU Nomor 23 Tahun 2014 tentang Pemerintahan Daerah.

UU Nomor 32 Tahun 2004 tentang Pemerintahan Daerah.

UU Nomor 6 Tahun 2014 tentang Desa.

Wahjudin, Sumpeno. 2011. Perencanaan Desa Terpadu. Banda Aceh: Reinforcement

Action and Development.

Widjaja, HAW. 2004. Otonomi Desa Merupakan Otonomi yang Bulat dan Utuh.

Jakarta: PT. RajaGrafindo Persada. 